\title{
DEVELOPMENT OF FOOD AND NUTRITION SCIENCES IN THE 100-YEAR HISTORY OF THE NATIONAL INSTITUTE OF HYGIENE IN POLAND
}

\author{
ROZWÓJ NAUK O ŻYWNOŚCI I ŻYWIENIU W 100-LETNIEJ HISTORII \\ PAŃSTWOWEGO ZAKŁADU HIGIENY W POLSCE
}

\author{
${ }^{1}$ Narodowy Instytut Zdrowia Publicznego - Państwowy Zakład Higieny \\ ${ }^{1}$ National Institute of Public Health - National Institute of Hygiene, Warsaw
}

\begin{abstract}
Issues related to nutrition and food safety in Poland are included in the hundred-year history of the National Institute of Hygiene (PZH), which exists since 1918.

The first scientific institution in Poland devoted to nutrition after the First World War was the Department of Biochemistry and Hygiene of Nutrition created in 1923 in the National School of Hygiene operating at the National Institute of Hygiene (PZH), whose director was Dr. Ludwik Rajchman. This Department was headed since 1925 by Kazimierz Funk, an outstanding scholar, who had already gained international fame as a discoverer of vitamins, and at PZH he investigated the effects of poor nutrition on health.

After departure of Kazimierz Funk from Poland, the issues related to nutrition were dealt with by Dr. Gustaw Szulc and Dr. Aleksander Szczygiet, who since 1938 was the head of the Department of Biochemistry and Nutrition Hygiene. In 1963, all issues related to nutrition were transferred from the National Institute of Hygiene (PZH) to the newly founded Institute of Food and Nutrition in Warsaw, whose director was Aleksander Szczygiet. Food safety issues went to the National Institute of Hygiene in 1935 after incorporating into its structure the State Department of Food and Consumers Goods operating in Warsaw since 1919. Thanks to this reorganization, National Institute of Hygiene became the headquarter for all State Departments of Food and Consumer Goods in Poland. As soon as in the third year of their activity (in 1921), the laboratories of the State Department of Food and Consumers Goods examined over 65,000 samples of food products, detecting adulterations, false labeling, harmful admixtures or spoiled products in $44 \%$ of cases. The State Departments of Food and Consumer Goods in 1952 were transformed into Sanitary-Epidemiological Stations and incorporated into the structures of the State Sanitary Inspection. National Institute of Hygiene obtained the status of a research institute whose tasks were besides the scientific activity, the postgraduate education of the personnel of this Inspection.

After the Second World War, prof. Stanistaw Krauze, who was appointed the head of the Department of Food Research and Articles of Common Use at the PZH in 1935, continued his mission. Prof. Stanistaw Krauze was recognized as the founder of the scientific bases of food control in Poland, food sciences and the initiator of microbiological food research. Prof. Stanistaw Krauze was the head of this Department of PZH until 1962. Another head of this Department, prof. dr h.c. Maksym Nikonorow, introduced research on pesticide residues, food monitoring studies, as well as toxicological testing using laboratory animals, opening a new quality in the assessment of food safety. After his retirement this Department was led by prof. Halina Mazur (1981-1990) and assoc. prof. Kazimierz Kartowski (1990-2010). Since 2011 dr Jacek Postupolski is a head of this Department, which in 2012 has changed its name to the Department of Food Safety. The scientific staff of this Department, besides conducting scientific research, service, and educational activities, acts as experts for the Minister of Health, the Minister of Agriculture, and other national authorities, and cooperates with the FAO/WHO, the European Commission and Food and Feed Safety Authority (EFSA). In the Department there are accredited laboratories serving as the National Reference Laboratories (NRLs) which cooperate with the European Union Reference Laboratories (EU-RLs).
\end{abstract}

Key words: nutrition, food safety, history of food control, consumer goods, PZH, Poland

\section{STRESZCZENIE}

Zagadnienia związane z żywieniem i bezpieczeństwem żywności w Polsce są wpisane w stuletnią historię Państwowego Zakładu Higieny (PZH), który istnieje od 1918 roku.

Pierwszą w Odrodzonej Polsce placówką naukową zajmującą się sprawami żywienia był Oddział Biochemii i Higieny Odżywiania utworzony w 1923 r. w Państwowej Szkole Higieny działającej przy Państwowym Zakładzie 
Higieny (PZH), którego dyrektorem był dr Ludwik Rajchman. Na czele tego Oddziału w 1925 r. stanął Kazimierz Funk wybitny uczony, który wcześniej już zyskał międzynarodową sławę jako odkrywca witamin, a w PZH zajął się badaniem skutków nieprawidłowego żywienia na zdrowie. Po wyjeździe Funka z Polski, zagadnieniami żywienia zajmował się dr Gustaw Szulc i dr Aleksander Szczygiet, który od 1938 r. był kierownikiem Oddziału Biochemii i Higieny Odżywiania, którego nazwę później zmieniono na Dział Higieny Żywienia PZH. W 1963 roku wszystkie zagadnienia związane z żywieniem zostały przeniesione z Państwowego Zakładu Higieny do nowo powstałego Instytutu Żywności i Żywienia w Warszawie, którego dyrektorem został Aleksander Szczygiet.

Zagadnienia bezpieczeństwa żywności trafiły do PZH w 1935 r. po włączeniu do jego struktury Państwowego Zakładu Badania Żywności i Przedmiotów Użytku, samodzielnie funkcjonującego w Warszawie już od 1919 r. Dzięki tej reorganizacji Państwowy Zakład Higieny stał się centralą dla pozostałych Państwowych Zakładów Badania Żywności funkcjonujących w Polsce, które stały się jego filiami. Już w trzecim roku swojego istnienia (w 1921 r), laboratoria tych Zakładów zbadały łącznie ponad 65 tysięcy próbek produktów spożywczych, stwierdzając w 44\% przypadków zafałszowania, fałszywe oznakowanie, szkodliwe domieszki lub zepsute produkty spożywcze. Państwowe Zakłady Badania Żywności i Przedmiotów Użytku będące filiami PZH w 1952 r. zostały przekształcone w stacje sanitarno-epidemiologiczne i włączone w struktury Państwowej Inspekcji Sanitarnej. PZH uzyskał status instytutu naukowo-badawczego, którego jednym z zadań była działalność naukowa i kształcenie podyplomowe kadr dla tej Inspekcji.

Po II Wojnie Światowej, kierownikiem Zakładu Badania Żywności i Przedmiotów Użytku w PZH był powołany jeszcze w 1935 r. Stanistaw Krauze, uznany za twórcę naukowych podstaw kontroli żywności w Polsce, nauki o żywności i inicjatora badań mikrobiologicznych żywności. Prof. Stanisław Krauze kierował Zakładem Badania Żywności i Przedmiotów Użytku PZH do 1962 r. Kolejny kierownik tego Zakładu w latach 1962-1981 prof. dr hab. dr h.c. Maksym Nikonorow, wprowadził badania pozostałości pestycydów, badania monitoringowe żywności, a także badania toksykologiczne na zwierzętach doświadczalnych otwierając nową jakość w ocenie bezpieczeństwa żywności. Po odejściu prof. Nikonorowa na emeryturę kolejnymi kierownikami Zakładu byli prof. dr hab. Halina Mazur (1981-1990) i doc. dr hab. Kazimierz Karlowski (1990-2010). Od 2011 r. kierownikiem tego Zakładu, który w 2012 r. zmienił nazwę na Zakład Bezpieczeństwa Żywności, jest dr Jacek Postupolski. Obecnie, pracownicy naukowi Zakładu oprócz badań naukowych, prowadzą działalność usługową i szkoleniową, są ekspertami dla Ministra Zdrowia, Ministra Rolnictwa i innych urzędów państwowych, a także współpracują z FAO/WHO, Komisją Europejską i Urzędem ds. Bezpieczeństwa Żywności (EFSA). W Zakładzie funkcjonują akredytowane laboratoria jako Narodowe Laboratoria Referencyjne (NRLs) współpracujące z Europejskimi Laboratoriami Referencyjnymi (EU-RLs).

Słowa kluczowe: żywienie, żywność, bezpieczeństwo żywności, historia kontroli żywności, przedmioty użytku, PZH

\section{WPROWADZENIE}

Zagadnienia związane z żywieniem i bezpieczeństwem żywności w Polsce są wpisane w stuletnią historię działalności Państwowego Zakładu Higieny $(\mathrm{PZH})$, który istnieje od 1918 roku. W Państwowym Zakładzie Higieny (obecna nazwa: Narodowy Instytut Zdrowia Publicznego - Państwowy Zakład Higieny), którego zakres działalności był bardzo szeroki, pracowało wielu wybitnych naukowców, dzięki którym instytucja ta zyskała uznanie w kraju i na świecie $(2,6,8,9,15)$.

\section{OKRES MIĘDZYWOJENNY}

Władze odrodzonej, wyniszczonej działaniami wojennymi Polski, przywiązywały ogromną wagę do stanu odżywienia ludności i jakości żywności, które wymagały pilnych działań w sferze organizacyjnej, naukowej i edukacyjnej. Ogromne potrzeby kraju spowodowały, że dwie niezmiernie istotne dla zdrowia społeczeństwa dziedziny, jakimi były żywienie i jakość zdrowotna żywności, musiały się rozwijać w szybkim tempie.
Utworzony w Państwowym Zakładzie Higieny (PZH) w 1923 roku Oddział Biochemii i Higieny Odżywiania Państwowej Szkoły Higieny był pierwszą w Polsce placówką naukową ds. żywienia. Prowadził badania naukowe $\mathrm{z}$ zakresu żywienia, a zwłaszcza wpływu żywienia na zdrowie oraz skutków nieprawidłowego żywienia. W 1925 roku, dr Ludwik Rajchman, któremu powierzono funkcję dyrektora PZH, sprowadził do Warszawy znanego biochemika - Kazimierza Funka, który miał rozwijać badania naukowe w Państwowym Zakładzie Higieny. Funk, uzyskał stypendium Fundacji Rockefellera, dzięki któremu mógł prowadzić badania nad insuliną, wpływem tiaminy na metabolizm węglowodanowy, badania nad niacyną i innymi zagadnieniami związanymi z prawidłowym żywieniem. Kazimierz Funk, pełniąc funkcję Kierownika Działu Biochemii w PZH, opublikował w 1925 r. w Medycynie Doświadczalnej i Społecznej artykuł pt. „Obecny stan nauki o witaminach” $(7,15)$. Razem ze współpracownikami opublikował także w czasopismach zagranicznych kilka prac, m.in. na temat roli insuliny w metabolizmie fosforu, syntezy witamin przez różne gatunki drożdży, zastosowania żelu koloidalnego żelaza do absorbcji witamin B i D czy wartości od- 
żywczej różnych warstw ziarna pszenicy i kukurydzy (15). Badania na temat witamin były kontynuowane przez jego asystentkę, mgr Zofię Kołodziejska, także po wyjeździe Funka z Polski w 1929 r. Badania te zostały zwieńczone opracowaniem 'Tablic witaminów', które ukazały się w czasopiśmie Zdrowie Publiczne Nr 11 i 12 w 1938 roku, jako pierwsza w Polsce publikacja na temat witamin. $Z$ powodu szybkiego wyczerpania nakładu oraz zmian, jakie zaszły w stanie wiedzy na temat witamin, tego samego roku ukazało się opracowanie, w postaci monografii, zawierającej aktualną wiedzę na temat witamin, przydatną zwłaszcza tym, którzy nie byli w stanie śledzić szybkiego postępu nauki o witaminach (5).

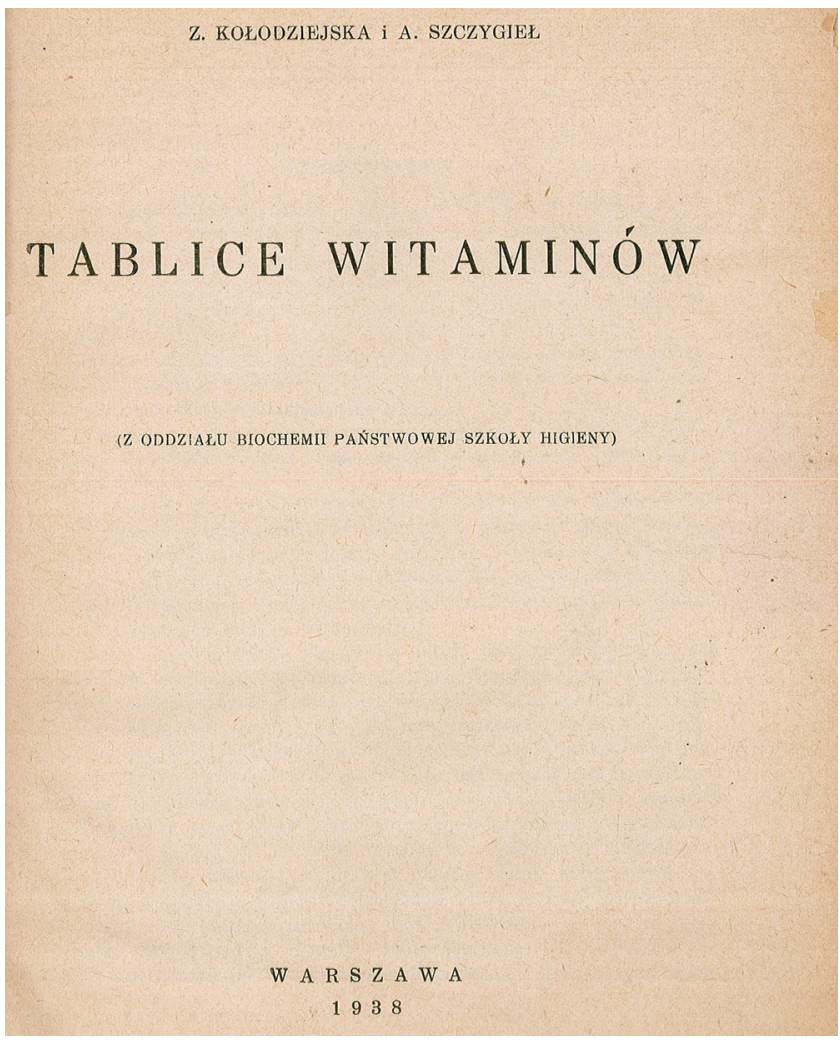

Fig. 1 'Tables of vitamins' by Zofia Kołodziejska and Aleksander Szczygiet, Warsaw 1938

Ryc. 1 'Tablice witaminów' autorstwa Zofii Kołodziejskiej i Aleksandra Szczygła, Warszawa 1938 r.

Z Oddziałem Biochemii i Higieny Odżywiania Państwowej Szkoły Higieny współpracował dr Stanistaw Kon ze Stacji Biologicznego Badania Żywności należącej wówczas do Ministerstwa Spraw Wewnętrznych i Aprowizacji. Prowadził on badania nad biologiczną wartością białek i zapotrzebowaniem człowieka na białko. Stacja ta później została włączona do Oddziału Biochemii i Higieny Odżywiania Państwowej Szkoły Higieny (15).

W 1931 r. dyrektorem Państwowego Zakładu Higieny został docent dr Gustaw Szulc. Tematyka jego prac naukowych w tym okresie dotyczyła roli żywie- nia $\mathrm{w}$ powstawaniu niektórych chorób (obecnie nazywanych metabolicznymi), żywienia sportowców i prawodawstwa z zakresu nadzoru nad żywnością. W celu umożliwienia dalszego rozwoju prac badawczych w tej dziedzinie, docent Szulc wysłał dr Aleksandra Szczygła na dwuletnie studia podyplomowe do profesora E.V. Mc Colluma w Johns Hopkins School of Hygiene and Public Health w Baltimore, Maryland, USA. Zaowocowało to $\mathrm{w}$ następnych latach powstaniem w Oddziale Biochemii i Higieny Odżywiania wielu publikacji naukowych i dwóch monografii z zakresu żywienia.

W latach 1935-1938 działalność naukowa Oddziału Biochemii i Higieny Odżywiania obejmowała badania nad wartością biologiczną produktów spożywczych i preparatów witaminowych, wpływem zjełczałych tłuszczów na zdrowie, zawartością witaminy $\mathrm{C}$ w owocach świeżych i przechowywanych. Opracowywano jadłospisy letnie i zimowe dla pracowników fizycznych i umysłowych oraz obliczano wartość kaloryczną i odżywczą posiłków wydawanych w kuchniach fabrycznych. Prowadzono także wykłady na kursach dla kontrolerów sanitarnych. Pracownicy Oddziału powoływani byli także w charakterze rzeczoznawców w sprawach jadłospisów dożywiania bezrobotnych, dzieci szkolnych oraz współpracowali w sprawach dotyczących żywienia z różnymi urzędami, instytucjami i organizacjami społecznymi. Przy Oddziale czynna była Stacja badania wartości odżywczej produktów spożywczych oraz kontroli organopreparatów $(17,18,19)$. Przy Państwowym Zakładzie Higieny istniała także specjalna Komisja ds. Organopreparatów, która rozpatrywała podania o rejestracje i dopuszczenie do obrotu preparatów hormonalnych. W 1937 roku rozpatrzono aż 70 wniosków (19).

W 1938 r. kierownictwo Oddziału Biochemii i Higieny Odżywiania Państwowej Szkoły Higieny objął dr Aleksander Szczygiet. Badania naukowe Oddziału koncentrowały się na oznaczaniu wartości biologicznej preparatów witaminowych, białek zbóż i uzupełnianiem białek zbóż białkami warzyw. Oznaczano także siłę bakteriobójczą środków stosowanych do sterylizacji naczyń mleczarskich (20).

Funkcjonujące w kraju od 1919 roku Państwowe Zakłady Badania Żywności i Przedmiotów Użytku, prowadziły szeroką działalność kontrolną, laboratoryjną i ekspertyzową, a bezpośredni nadzór nad nimi sprawowało Ministerstwo Zdrowia Publicznego (6, 10, 11). Państwowy Zakład Badania Żywności i Przedmiotów Użytku w Warszawie w 1921 roku, w trzecim roku swojego istnienia, zbadał ogółem ponad 35 tysięcy próbek produktów spożywczych, w tym aż 36\% stanowiły próbki zakwestionowane $\mathrm{z}$ powodu zafałszowania, fałszywego oznaczenia, zepsucia lub stosowania szkodliwych domieszek do żywności. Spośród zbadanych 349 
próbek przedmiotów użytku 35,2\% zakwestionowano z powodu niespełniania wymagań zdrowotnych. Do sądów i władz administracyjnych skierowano aż 5499 doniesień karnych. W 1922 roku odsetek zakwestionowanych próbek żywności wzrósł do ponad 50\% (14). Podobna sytuacja, pod względem odsetka kwestiono- wanych próbek produktów spożywczych w latach 1921 i 1922, była w filiach w Łodzi i Krakowie. Szczegółowe dane dotyczące zbadanych i zakwestionowanych próbek produktów spożywczych i przedmiotów użytku w Zakładach Warszawie, Łodzi i Krakowie w latach 1921 i 1922 zestawiono w Tabeli I.

Table I. Number of examined and questioned samples of food products and consumer goods in the State Department of Food and Consumers Goods in Warsaw, Lodz, Krakow w 1921 and 1922 (14)

Tabela I. Liczba zbadanych i zakwestionowanych próbek produktów spożywczych i przedmiotów użytku w Państwowych Zakładach Badania Żywności i Przedmiotów Użytku w Warszawie, Łodzi i Krakowie w latach 1921 i 1922 (14)

\begin{tabular}{|c|c|c|c|c|c|}
\hline \multirow{2}{*}{$\begin{array}{c}\text { Lokalizacja } \\
\text { Zakładu }\end{array}$} & \multirow{2}{*}{$\begin{array}{c}\text { Rok } \\
\text { badania }\end{array}$} & \multicolumn{2}{|c|}{ Produkty spożywcze } & \multicolumn{2}{|c|}{ Przedmioty użytku } \\
\cline { 3 - 6 } & 1921 & 35503 & $13112(36,1 \%)$ & 349 & $123(35,2 \%)$ \\
\hline \multirow{2}{*}{ Warszawa } & 1922 & 28213 & $14737(52,2 \%)$ & 177 & $16(9,04 \%)$ \\
\cline { 2 - 6 } & 1921 & 28663 & $15378(53,6 \%)$ & 216 & $56(25,9 \%)$ \\
\hline \multirow{2}{*}{ Łódź } & 1922 & 28213 & $14737(52,2 \%)$ & 177 & $16(9,04 \%)$ \\
\hline \multirow{2}{*}{ Kraków } & 1921 & 1051 & $453(43,1 \%)$ & 58 & $21(36,2 \%)$ \\
\cline { 2 - 6 } & 1922 & 1925 & $1144(59,4 \%)$ & 152 & $81(53,3 \%)$ \\
\hline \multirow{2}{*}{ Razem } & $\mathbf{1 9 2 1}$ & $\mathbf{6 5 2 1 7}$ & $\mathbf{2 8 9 4 3 ( 4 4 , 0 \% )}$ & $\mathbf{6 2 3}$ & $\mathbf{2 0 0}$ \\
\cline { 2 - 6 } & $\mathbf{1 9 2 2}$ & $\mathbf{5 8 3 5 1}$ & $\mathbf{3 0 6 1 8 ( 5 4 , 6 \% )}$ & $\mathbf{5 0 6}$ & $\mathbf{1 1 3}$ \\
\hline
\end{tabular}

Jak wynika ze szczegółowego sprawozdania opublikowanego przez Ministerstwo Zdrowia Publicznego, w Państwowych Zakładach Badania Żywności i Przedmiotów Użytku w Warszawie, Łodzi i Krakowie, w latach 1921 i 1922, najwięcej kwestionowano próbek mleka i przetworów mlecznych (śmietana, śmietanka, masło) sprzedawanych na targowiskach (14). Wykonywano także badania toksykologiczne na obecność trucizn w pokarmach. W Warszawie w $1921 \mathrm{r}$. pod kątem obecności trucizn zbadano 20 próbek żywności stwierdzając $\mathrm{w} 17 \mathrm{z}$ nich wynik dodatni, natomiast w 1922 r. na 79 zbadanych próbek 22 próbki dały wynik dodatni.

Badania wykonywane przez Państwowe Zakłady Badania Żywności i Przedmiotów Użytku prowadzono na podstawie Państwowej Zasadniczej Ustawy Sanitarnej i dekretu z 1919 r. o nadzorze nad wyrobem i sprzedażą artykułów. Opłaty za badania pobierano zgodnie z cennikiem ujętym w Rozporządzeniu Ministra Zdrowia Publicznego z 1919 r. $(10,12)$. Organizację dozoru nad wyrobem, sprzedażą i wprowadzaniem do obrotu artykułów żywności i przedmiotów użytku określało, wydane później z mocą ustawy, Rozporządzenie Prezydenta Rzeczypospolitej z 1928 r. (Dz. U z 1928 r, nr. 36, poz. 343) (13). Rozporządzenie to stosowane było w praktyce przez wiele lat, zwłaszcza w odniesieniu do przedmiotów użytku, i zostało uchylone dopiero 1.01.2003 r.
1 kwietnia 1935 r. Państwowe Zakłady Badania Żywności i Przedmiotów Użytku zostały włączone do Państwowego Zakładu Higieny. Samodzielny Państwowy Zakład Badania Żywności i Przedmiotów Użytku z siedzibą w Warszawie, którego Dyrektorem był dr Stanisław Krauze, został włączony do Państwowego Zakładu Higieny i stał się Działem PZH, a Państwowe Zakłady Badania Żywności i Przedmiotów Użytku w Łodzi, Poznaniu i Krakowie oraz istniejące Oddziały w Gdyni i Wilnie stały się filiami Państwowego Zakładu Higieny (17). W następnych latach przybywały nowe filie PZH (1), w których uruchamiano oddziały badania żywności i przedmiotów użytku.

Wraz z włączeniem do PZH Państwowych Zakładów Badania Żywności i Przedmiotów Użytku znacznie rozszerzył się zakres jego działalności, w tym także naukowej.

Dział Badania Żywności i Przedmiotów Użytku w centrali PZH odpowiedzialny był za nadzór nad artykułami żywności i przedmiotami użytku w m.st. Warszawie i w województwach: warszawskim, białostockim, poleskim i wołyńskim. W tym czasie istniała pilna potrzeba przeprowadzenia kontroli w tych województwach, ponieważ w niektórych miastach nie było kontroli artykułów żywności w ciągu ostatnich 10 lat, a w innych nie było jej dotąd wcale. Na konieczność takiej kontroli wskazywała duża liczba artykułów spo- 
żywczych, kwestionowanych w niektórych województwach z powodu zafałszowania, zepsucia lub obecności szkodliwych substancji, która przekraczała niekiedy nawet $50 \%$. W miesiącach letnich, Dział zajmował się również kontrolą napojów chłodzących na całym podległym mu terenie (17).
W 1935 r. w Dziale w Warszawie ogółem zbadano 20067 próbek. Odsetek zakwestionowanych próbek wynosił około 30\%. Najwięcej uwagi poświęcano kontroli mleka i jego przetworów, których ok. 50\% było kwestionowanych [17].

Liczbę zbadanych i zakwestionowanych próbek w 1935 r. zestawiono w Tabeli II.

Table II. Number of examined and questioned samples of food products and consumer goods in the Department of Food and Consumer Goods of PZH in Warsaw and PZH branches in 1935 (17)

Tabela II. Liczba zbadanych i zakwestionowanych próbek produktów spożywczych i przedmiotów użytku w Dziale Badania Żywności i Przedmiotów Użytku PZH w Warszawie oraz filiach PZH w 1935 r. (17)

\begin{tabular}{|c|c|c|c|c|}
\hline \multirow{2}{*}{ Centrala i filie PZH } & \multicolumn{2}{|c|}{ Produkty spożywcze } & \multicolumn{2}{c|}{ Przedmioty użytku } \\
\cline { 2 - 5 } & zbadane & zakwestionowane & zbadane & zakwestionowane \\
\hline Warszawa & 20067 & $6107(30,4 \%)$ & 55 & 2 \\
\hline Kraków & 15907 & $3575(22,47)$ & 59 & 22 \\
\hline Łódź & 23927 & $5308(22,18)$ & 122 & 175 \\
\hline Poznań & 5424 & $2183(40,2 \%)$ & 284 & 16 \\
\hline Wilno & 4424 & $1495(33,7 \%)$ & 112 & 2 \\
\hline Gdynia & 3826 & $1640(42,8 \%)$ & 7 & $\mathbf{2 4 5}$ \\
\hline OGóLEM & $\mathbf{7 3 5 7 5}$ & $\mathbf{2 0 ~ 3 0 8 ~ ( 2 7 , 6 \% )}$ & $\mathbf{6 3 9}$ & \\
\hline
\end{tabular}

W 1935 r. istotnym zadaniem Działu Badania Żywności i Przedmiotów Użytku w PZH było także utrzymywanie kontaktów $\mathrm{z}$ handlem i przemysłem spożywczym w celu uzgodnienia przepisów dotyczących kontroli żywności. Prace naukowe Działu w tym czasie ukierunkowane były także na zbieranie materiałów do polskiego kodeksu żywnościowego czyli ujednoliconych metod badania żywności i przedmiotów użytku, którego brak dotkliwie odczuwano przy prowadzeniu kontroli żywności $(3,17)$. Prace badawcze w tym czasie dotyczyły barwników dozwolonych w Polce do barwienia żywności oraz proszków do pieczenia ciast. Prowadzono także badania mąki i pieczywa oraz soli, w związku z wprowadzeniem od 1 stycznia 1935 r. na terenie województwa krakowskiego sprzedaży tylko jodowanej soli spożywczej, w której zawartość jodku potasu $(\mathrm{KJ})$ powinna wynosić około $5 \mathrm{~g}$ na tonę soli, z dopuszczalnymi odchyleniami o 2 gramy (17).

W latach 1936-1938 nastąpił rozwój organizacyjny Działu i Oddziałów badania żywności w filiach PZH, w których wykonywano tysiące analiz $(18,19,20)$. Dział w Warszawie był odpowiedzialny za poziom prac Oddziałów. Utworzenie Działu Wodnego i przejęcie przez niego badań próbek wody, spowodowało, że ogólna liczba analiz, wykonywanych w Dziale Badania Żywności w PZH i w filiach, spadła z 73575 do 68929 próbek. Odsetek próbek produktów spożywczych zakwestionowanych w 1936 r. wynosił 24,4\% $(27,6 \% \mathrm{w} 1935 \mathrm{r}$ ) $)$ i w porównaniu z krajami zachodnio-europejskimi był bardzo wysoki (18).

Table III. Number of examined and questioned samples of food products and consumer goods in the Department of Food and Consumer Goods of PZH in Warsaw and PZH branches in 1936 (18)

Tabela III. Liczba zbadanych i zakwestionowanych próbek produktów spożywczych i przedmiotów użytku w Dziale Badania Żywności i Przedmiotów Użytku PZH w Warszawie oraz filiach PZH w 1936 r. (18)

\begin{tabular}{|c|c|c|c|c|}
\hline \multirow{2}{*}{ Centrala i filie PZH } & \multicolumn{2}{|c|}{ Produkty spożywcze } & \multicolumn{2}{c|}{ Przedmioty użytku } \\
\cline { 2 - 5 } & zbadane & zakwestionowane & zbadane & zakwestionowane \\
\hline Warszawa & 18408 & $4484(26,5 \%)$ & 326 & 111 \\
\hline Kraków & 14025 & $2411(17,2 \%)$ & 163 & 23 \\
\hline Gdynia & 3809 & $1658(43,5 \%)$ & 137 & 12 \\
\hline Wilno & 5923 & $1499(25,3 \%)$ & 167 & 92 \\
\hline Poznań & 4387 & $1753(40,0 \%)$ & 88 & 20 \\
\hline Lódź & 22377 & $4609(20,6 \%)$ & $\mathbf{9 0 0}$ & $\mathbf{2 6 0}$ \\
\hline OGÓLEM & $\mathbf{6 8 9 2 9}$ & $\mathbf{1 6 8 1 4}(\mathbf{2 4 , 4 \% )}$ & & 2 \\
\hline
\end{tabular}


W 1937 r. powstały dwa nowe Oddziały badające żywność w Łucku i Stanisławowie. Z ogólnej liczby 12 filii PZH aż 7 posiadało już Oddziały badania żywności. Spośród zbadanych ogółem 72658 próbek żywności zakwestionowano 18126 próbek (25\%). W no- wych oddziałach w Łucku i Stanisławowie zbadano ok. 1500 próbek żywności. Liczbę próbek zbadanych i zakwestionowanych w Dziale PZH w Warszawie i filiach w 1937 zestawiono w Tabeli IV (19).

Table IV. Number of examined and questioned samples of food products and consumer goods in the Department of Food and Consumer Goods of PZH in Warsaw and PZH branches in 1937 (19)

Tabela IV. Liczba zbadanych i zakwestionowanych próbek produktów spożywczych i przedmiotów użytku w Dziale Badania Żywności i Przedmiotów Użytku PZH w Warszawie oraz filiach PZH w 1937 r. (19)

\begin{tabular}{|c|c|c|c|c|}
\hline \multirow{2}{*}{ Centrala i filie PZH } & \multicolumn{2}{|c|}{ Produkty spożywcze } & \multicolumn{2}{|c|}{ Przedmioty użytku } \\
\hline & zbadane & zakwestionowane & zbadane & zakwestionowane \\
\hline Warszawa & 18010 & $4378(24,3 \%)$ & 278 & 108 \\
\hline Kraków & 14911 & $2663(17,9 \%)$ & 156 & 64 \\
\hline Gdynia & 3611 & $1354(37,5 \%)$ & 21 & 1 \\
\hline Wilno & 8738 & $1220(14,0 \%)$ & 255 & 24 \\
\hline Poznań & 5342 & $2424(45,4 \%)$ & 322 & 225 \\
\hline Łódź & 20550 & $5333(25,9 \%)$ & 128 & 40 \\
\hline Łuck & 996 & $466(46,8 \%)$ & 18 & 9 \\
\hline Stanisławów & 500 & $288(57,6 \%)$ & 6 & 2 \\
\hline OGÓLEM & 72658 & $18126(24,9 \%)$ & 1184 & 473 \\
\hline
\end{tabular}

Liczbę próbek zbadanych i zakwestionowanych w filiach Państwowego Zakładu Higieny w 1938 r. podano w Tabeli V.

Table V. Number of examined and questioned samples of food products and consumer goods in the Department of Food and Consumer Goods of PZH in Warsaw and PZH branches in 1938 (20)

Tabela V. Liczba zbadanych i zakwestionowanych próbek produktów spożywczych i przedmiotów użytku w Dziale Badania Żywności i Przedmiotów Użytku PZH w Warszawie oraz filiach PZH w 1938 roku (20)

\begin{tabular}{|c|c|c|c|c|}
\hline \multirow{2}{*}{ Centrala i filie PZH } & \multicolumn{2}{|c|}{ Produkty spożywcze } & \multicolumn{2}{c|}{ Przedmioty użytku } \\
\cline { 2 - 5 } & zbadane & zakwestionowane & 250 & 112 \\
\hline Warszawa & 14859 & $3277(22,05 \%)$ & 134 & 55 \\
\hline Kraków & 12864 & $2764(21,49 \%)$ & 35 & 9 \\
\hline Gdynia & 4305 & $1870(43,44 \%)$ & 324 & 186 \\
\hline Wilno & 9261 & $1204(13,93 \%)$ & 63 & 28 \\
\hline Poznań & 5727 & $1959(34,21 \%)$ & 99 & 47 \\
\hline Łódź & 16337 & $4957(30,34 \%)$ & 34 & 7 \\
\hline Łuck & 3994 & $1452(36,35 \%)$ & 24 & 23 \\
\hline Stanisławów & 3023 & $1106(38,30 \%)$ & 16 & 10 \\
\hline Lublin & 748 & $416(55,61 \%)$ & 7 & 3 \\
\hline Lwów & 238 & $95(39,92 \%)$ & 183 & 61 \\
\hline Kielce & 145 & $76(52,41 \%)$ & $\mathbf{1 3 5 5}$ & \\
\hline Katowice & 7669 & $1200(15,65 \%)$ & $\mathbf{5 2 5}$ \\
\hline OGÓŁEM & $\mathbf{7 9 0 3 5}$ & $\mathbf{2 0 4 6 2 ( 2 5 , 8 9 \% )}$ & & 29 \\
\hline
\end{tabular}

W 1938 r. powstały 3 nowe Oddziały Badania Żywności: w Lublinie, Lwowie i Kielcach (20).

Próbki do badań nadsyłali kontrolerzy z Działu PZH i filii, instytucje państwowe i samorządowe oraz osoby prywatne. Aby zapewnić ścisły kontakt Centrali PZH z filiami, każdego roku odbywały się 2-3 dniowe wizytacje w Oddziałach filii. Polegały one na dyskusjach w sprawach metod analitycznych stosowanych w kontroli żywności i przedmiotów użytku oraz wydawanych orzeczeń. Miały one na celu zapewnienie ujednoliconego postępowania przy interpretacji wy- ników. Aby zapewnić stosowanie przy badaniu żywności i przedmiotów użytku ujednoliconych metod analitycznych, Centrala w Warszawie organizowała specjalne kursy doszkalające dla pracowników filii. Profesor Stanisław Krauze przywiązywał dużą wagę do opracowania i wydania Polskiego Kodeksu Żywnościowego, zawierającego ujednolicone metody badania żywności i przedmiotów użytku. Temat ten poruszał bardzo często, zwłaszcza, wówczas gdy był odpowiedzialny za kontrolę żywności i przedmiotów użytku w kraju. Prace nad Kodeksem Żywnościowym 
rozpoczęto przed wybuchem wojny, ale niestety Ministerstwo Opieki Społecznej, które kierowało wtedy kontrolą żywności w kraju, nie dało żadnych środków finansowych na jego opracowanie. Zbliżające się już niebezpieczeństwo wybuchu wojny spowodowało, że uwaga była skupiona na sprawach praktycznych. Rozwijający się przemysł rybny wymagał zwiększonej jego kontroli, gdyż, jak wykazano, szereg przetworów rybnych (szproty, homary itp.) wprowadzanych do obrotu handlowego, nie odpowiadało podstawowym wymaganiom higienicznym (20).

Kontynuowane były naukowe posiedzenia referatowe $\mathrm{z}$ zakresu badania i przeprowadzania kontroli żywności dla pracowników Działu badania żywności PZH i poległych mu filii.

Po wybuchu II Wojny Światowej w 1939 r. i przejęciu PZH przez władze okupacyjne, personel Oddziału Biochemii i Higieny Odżywiania Państwowej Szkoły Higieny został przeniesiony do Oddziału Kontroli Organopreparatów i Witamin. Pracownicy tego Oddziału zajmowali się produkcją namiastki cukru (tzw. dulcyny), badaniem preparatów organicznych i witamin, a także współpracowali ze Stołecznym Komitetem Samopomocy Społecznej rozdzielając tran i witaminy dla dzieci. Nauczanie o żywieniu i żywności musiało zejść do podziemia, gdzie dr Aleksander Szczygiet prowadził wykłady na tajnym Wydziale Lekarskim Uniwersytetu Warszawskiego.

Podczas Powstania Warszawskiego pracownicy, którzy pozostali w PZH, zapisali chlubną kartę w jego dziejach. Bronili budynków PZH przed pożarami i dewastacją, odwlekając termin ich wysadzenia przez okupantów, ukrywali sprzęt i wyposażenie laboratoriów, prowadzili aptekę i szpital powstańczy. Gmach PZH udało się uratować.

\section{OKRES PO II WOJNIE ŚWIATOWEJ}

\section{Zakład Higieny Żywienia}

Po zakończeniu wojny w 1945 r. nie było pewności czy zrujnowana Warszawa zostanie stolicą, więc podjęto decyzję o tymczasowym przeniesieniu centrali PZH do Łodzi, pozostawiając w Warszawie jedynie filię, w której kierownikiem Oddziału Biochemii i Higieny Odżywiania, po uzyskaniu stopnia docenta higieny, został Aleksander Szczygieł. W tym czasie pracę w Oddziale podjęły mgr inż. Maria Romanowska-Szczygłowa i mgr inż. Jadwiga Rudowska-Koprowska oraz kilku laborantów i techników, co umożliwiło planowanie i realizację zadań laboratoryjnych.

6 września 1946 roku, ówczesny Dyrektor PZH, Feliks Przesmycki, w miejsce Oddziału Biochemii i Higieny Odżywiania, powołał Zakład Higieny Żywienia, którego najważniejszymi zadaniami było:

- zapoznanie się z nowymi zdobyczami nauki o żywieniu opracowanie i wprowadzenie nowych metod badawczych w dziedzinie żywienia

poznanie skutków wadliwego żywienia ludności Polski, zwłaszcza dzieci i młodzieży

- opracowanie programu racjonalizacji żywienia

- organizowanie szkoleń dla kadry żywieniowców i pomoc w szkoleniu techników żywienia

- przygotowanie materiałów do nauczania (podręczniki, tabele składu i wartości odżywczych środków spożywczych, normy wyżywienia)

- opracowanie wytycznych dotyczących żywienia poszczególnych grup ludności

- organizacja zakładów żywienia zbiorowego

- żywienie w zamkniętych zakładach leczniczych

Zapotrzebowanie na publikacje z Zakładu Higie-

ny Żywienia szybko wzrastało, szczególnie w zakresie nauczania i badań usługowych zlecanych przez Ministerstwo Zdrowia, Ministerstwo Aprowizacji i Handlu, Ministerstwo Oświaty i Szkolnictwa Wyższego, Centralny Zarząd Szkolnictwa Zawodowego, Ministerstwo Handlu Wewnętrznego, Ministerstwa Przemysłu i Skupu, a także różne organizacje społeczno-gospodarcze.

Zakład Higieny Żywienia PZH zajmował się badaniami nad stanem odżywienia i sposobem żywienia różnych grup ludności, a zwłaszcza dzieci i młodzieży. W badaniach tych stosowano metody antropometryczne i biochemiczne. Przetlumaczono angielskie, a potem opracowano własne, polskie tabele składu i wartości odżywczych środków spożywczych oraz normy żywienia. Publikowano liczne artykuły naukowe i monografie. Szczególnie przydatna była monografia pt. „Normy wyżywienia dla 18 grup ludności”. Normy te wykorzystywano przy planowaniu produkcji, przetwórstwa i obrotu żywnością, a także do poprawy żywienia zbiorowego. Nawiązano kontakty z FAO, WHO, Międzynarodową Unią Nauk Żywieniowych i innymi organizacjami (21).

Dla tej szybko rozwijającej się w kraju dziedziny $\mathrm{z}$ zakresu żywienia brakowało wyszkolonych kadr i dlatego Zakład Higieny Żywienia PZH starał się wypełnić tę lukę. W 1946 r. uczestniczył w organizacji Studium Wyżywienia Społecznego przy Wydziale Ogrodniczym SGGW, którego zadaniem było szkolenie żywieniowców na poziomie akademickim. Studium działało do 1950 r. W tym samym roku na Akademii Medycznej w Warszawie utworzono Oddział Sanitarno-Higieniczny, a w nim Katedrę i Zakład Żywienia, które mieściły się w gmachu PZH, wykorzystując jego kadrę i wyposażenie. Kiedy w 1956 r. w miejsce Oddziału Sanitarno-Higienicznego powstało Studium Sanitarno-Higieniczne, katedra i Zakład Żywienia weszły w jego skład. Wtedy też w PZH na dużą skalę prowadzono kursy dla stacji sanitarno-epidemiologicznych i pracowników katedr higieny Akademii Medycznych. 
W 1954 r. Zakład Higieny Żywienia PZH liczył 20 pracowników naukowych, 9 inżynieryjno-technicznych, 5 osób pomocy laboratoryjnych i 3 osoby administracji. Zajmował powierzchnię $440 \mathrm{~m}^{2}$. Ponieważ Zakład Higieny Żywienia z trudem mógł już realizować nakładane na niego nowe, stale rozszerzane zadania, powrócono do projektu utworzenia Instytutu Żywności i Żywienia (IŻŻ), który jeszcze przed wojną wysunął ówczesny dyrektor Państwowego Zakładu Higieny dr Gustaw Szulc. Minister Zdrowia zaakceptował ten wniosek i powołał Biuro Pełnomocnika ds. budowy nowego gmachu dla IŻŻ. Udało się uzyskać kilka pomieszczeń na terenie Warszawy, m.in. w miejscu przyszłego nowego gmachu IŻŻ przy ul. Powsińskiej 61. Funkcjonujące w tym czasie w PZH dwa współpracujące ze sobą Zakłady: Zakład Higieny Żywienia oraz Zakład Badania Żywności i Przedmiotów Użytku, podlegały zastępcy Dyrektora PZH ds. Higieny - Marcinowi Kacprzakowi.

Powołany w 1963 r. w miejsce Zakładu Higieny Żywienia - Instytut Żywności i Żywienia - początkowo mieścił się w czterech punktach w Warszawie: w PZH przy ul. Chocimskiej 24, przy ul. Wolność 9, przy ul. Rakowieckiej 36 i przy ul. Powsińskiej 61. Pełnomocnikiem ds. budowy nowego gmachu dla IŻŻ został doc. Aleksander Szczygiet. Po uzyskaniu terenu pod budowę, w 1960 r. zaczęto prowadzić rozmowy z Organizacją ds. Wyżywienia i Rolnictwa Narodów Zjednoczonych (FAO) w sprawie dotacji na wyposażenie Instytutu. FAO wyraziło zgodę i przyznało dotację FS/FAO/ONZ na rozwiązywanie problemów związanych z żywnością i żywieniem w Polsce. Dotacja była przeznaczona dla różnych resortów gospodarczych, lecz kluczowe miejsce miał zajmować Instytut Żywności i Żywienia.

Dyrektor projektu Dr F. Aylward wspólnie ze stroną polską opracował plan wykorzystania dotacji. Instytut Żywności i Żywienia uzyskał środki finansowe na wyposażenie, stypendia i ekspertów. Pełnomocnikiem Rządu ds. realizacji umowy został ówczesny wiceminister Zdrowia i Opieki Społecznej - prof. dr Jan Kostrzewski. Gmach Instytutu Żywności i Żywienia zbudowano w ciągu 5 lat i kilku miesięcy. Uroczyste jego otwarcie odbyło się 2 sierpnia 1968 r. z udziałem Dyrektora Generalnego FAO (23).

Utworzony Instytut Żywności i Żywienia w Warszawie przy ul. Powsińskiej 61, którego Dyrektorem został profesor Aleksander Szczygiel, realizował zadania wykonywane wcześniej przez Zakład Higieny Żywienia PZH, natomiast współpracujący z nim Zakład Badania Żywności i Przedmiotów Użytku pozostał w PZH przy ul. Chocimskiej 24 i prowadził działalność naukową i usługową w zakresie jakości zdrowotnej żywności.

\section{Zakład Badania Żywności i Przedmiotów Użytku}

Po II Wojnie Światowej, kierownikiem Zakładu Badania Żywności i Przedmiotów Użytku PZH był powołany jeszcze w 1935 r. dr Stanistaw Krauze. (8). Doprowadził on do utworzenia najpierw w filiach PZH, a potem w stacjach sanitarno-epidemiologicznych Pracowni Mikrobiologii Żywności.

Prof. Stanistaw Krauze kierował Działem Badania Żywności i Przedmiotów Użytku PZH aż do 1962 r. Prof. Krauze pracując w PZH jednocześnie pracował w Katedrze Nauki o Środkach Spożywczych na Wydziale Farmaceutycznym Uniwersytetu Warszawskiego (od 1950 r. Akademii Medycznej). W latach 19461949 odbywał podróże naukowe do Anglii, Szwajcarii i Szwecji pogłębiając swoją wiedzę i zapoznając się $\mathrm{z}$ najnowszymi osiągnięciami $\mathrm{w}$ dziedzinie badania środków spożywczych i przedmiotów użytku $(4,8$, 22).

Z inicjatywy i dzięki staraniom prof. Stanistawa Krauzego w 1950 r. powołano do życia wydawane w PZH czasopismo naukowe „Roczniki Państwowego Zakładu Higieny", którego był pierwszym redaktorem naczelnym pełniąc tę funkcję w latach 1950-1955, 1959 i 1962-1964. Od tego momentu pracownicy PZH mieli już własne czasopismo, poświęcone zagadnieniom żywienia i bezpieczeństwu żywności, w którym mogli publikować prace naukowe $\mathrm{z}$ tych dziedzin.

W 1957 r. Zakład Badania Żywności i Przedmiotów Użytku we współpracy z Instytutem Sadownictwa prowadził badania preparatu 'Azotox' zawierającego DDT, który stosowany był do oprysku drzew owocowych. Wyniki tych badań posłużyły do wyznaczenia okresów karencji po opryskach i ograniczenia pozostałości pestycydów w owocach. W tym czasie pestycydy chloroorganiczne (wśród nich DDT) powszechnie były stosowane, a ich pozostałości wykrywano w różnych produktach spożywczych, zarówno roślinnych jak i zwierzęcych.

Prof. Krauze uznany jest za twórcę naukowych podstaw kontroli żywności w Polsce. Był także twórcą bromatologii (nauki o żywności) i inicjatorem badań mikrobiologicznych żywności $(8,22)$.

W 1957 r. ukazał się podręcznik pt. „Metody mikrobiologicznego badania produktów żywnościowych" autorstwa Marii Burbianki, specjalistki z zakresu mikrobiologii żywności. Doczekał się on pięciu kolejnych unowocześnionych wydań $(8,21)$.

Profesor Krauze po objęciu Katedry Bromatologii w 1962 r. pracował już tylko w Akademii Medycznej w Warszawie. Stanowisko kierownika Zakładu Badania Żywności i Przedmiotów Użytku PZH, po prof. Krauze, objął prof. dr hab. farm. Maksym Nikonorow, który pracował w tym Zakładzie od ukończenia studiów farmaceutycznych jeszcze przed wojną, początkowo jako asystent, a po wojnie jako kierownik 
Pracowni Toksykologii w tym Zakładzie. Profesor Nikonorow kierował Zakładem od 1962 r. do przejścia na emeryturę w 1981 r. Był współtwórcą nauki o środkach spożywczych oraz stworzył polską szkołę toksykologii żywności. Jako pierwszy rozpoczął badania monitoringowe żywności w zakresie szkodliwych dla zdrowia zanieczyszczeń występujących w produktach spożywczych (8). Profesor Nikonorow pełnił też funkcję zastępcy Dyrektora ds. Higieny w PZH, a w latach 1982-1985 był redaktorem naczelnym kwartalnika „Roczniki Państwowego Zakładu Higieny” wydawanego przez PZH nieprzerwanie od 1950 r. do chwili obecnej.

Pod koniec lat 60. w Zakładzie Badania Żywności i Przedmiotów Użytku w szerokim zakresie prowadzono badania pozostałości pestycydów w środkach spożywczych metodami: kolorymetryczną, polarograficzną, chromatografii bibułowej i cienkowarstwowej oraz badano dynamikę zanikania tych pozostałości w owocach i warzywach. W latach 70., w miarę doskonalenia aparatury badawczej, wprowadzono nowoczesne metody wykrywania i oznaczania pozostałości pestycydów fosforoorganicznych w owocach cytrusowych, wykorzystując do tego celu własną adaptację enzymatycznej zautomatyzowanej metody oznaczania pozostałości insektycydów fosforoorganicznych. Prowadzono też badania toksykologiczne w zakresie toksyczności ostrej, podostrej i przewlekłej pestycydów na zwierzętach doświadczalnych.

W Pracowni mikrobiologii żywności oceniano zanieczyszczenia mikrobiologiczne w żywności i przedmiotach użytku. Opracowywano nowe metody badania jakości mikrobiologicznej w żywności, środków kosmetycznych i preparatów chemii gospodarczej oraz opiniowano dokumenty międzynarodowe i normy krajowe w zakresie parametrów mikrobiologicznych.

W Zakładzie zajmowano się także badaniami i oceną higieniczną wyrobów z tworzyw sztucznych, w tym migracją do żywności szkodliwych dla zdrowia substancji pomocniczych (zmiękczaczy, stabilizatorów i przeciwutleniaczy) z opakowań i innych przedmiotów użytku. Dokonywano oceny higienicznej wyrobów kosmetycznych i środków myjących, czyszczących i piorących oraz surowców stosowanych do ich produkcji. Badano i dokonywano oceny substancji dodatkowych i niektórych zanieczyszczeń szkodliwych dla zdrowia występujących w żywności. Opracowywano także metody badań toksykologicznych i ustalano ich zakres dla nowo wprowadzanych środków spożywczych, dodatków do żywności i przedmiotów użytku.

O intensywności prac badawczych wykonywanych w Zakładzie Badania Żywności i Przedmiotów w Użytku może świadczyć liczba 261 oryginalnych prac naukowych opublikowanych w latach 1964-1973 $(4,21)$.
W skład Zakładu Badania Żywności i Przedmiotów Użytku PZH wchodziły wówczas:

- Pracownia Higieny Żywności

- Pracownia Badania Substancji Obcych w Żywności

- Pracownia Badania Zanieczyszczeń Chemicznych

Żywności (wcześniej Pracownia Fizyko-Chemiczna)

- Pracownia Mikrobiologii Żywności

- Pracownia Toksykologii

- Pracownia Badania Pozostałości Pestycydów

(w 1986 r. przeniesiona do Zakładu Toksykologii

Środowiskowej PZH)

- Pracownia Badania Wyrobów z Tworzyw Sztucznych

- Pracownia Badania Środków Kosmetycznych

i Preparatów Chemii Gospodarczej (wcześniej

Pracownia Higieny Przedmiotów Użytku)

Badania naukowe koncentrowały się na oznaczaniu zanieczyszczeń chemicznych i mikrobiologicznych żywności, dodatków do żywności i antybiotyków oraz innych substancji szkodliwych występujących w żywności i przedmiotach użytku.

Zakład Badania Żywności i Przedmiotów Użytku publikował także liczne metody analityczne w Wydawnictwach Metodycznych PZH, z przeznaczeniem dla laboratoriów stacji sanitarno-epidemiologicznych. Były one wykorzystywane przy badaniu próbek żywności i przedmiotów użytku pobieranych w ramach urzędowej kontroli. Publikacje te ukazywały się systematycznie w miarę opracowywania nowych metod, zastosowania doskonalszej aparatury i nowych technologii w badaniu bezpieczeństwa zdrowotnego żywności.

Zakład PZH obejmował kontrolą merytoryczną Oddziały Higieny Żywności i Przedmiotów Użytku w Wojewódzkich Stacjach Sanitarno-Epidemiologicznych w zakresie badań laboratoryjnych oraz oceny sanitarnej obiektów wytwarzających żywność.

W 1981 r. do badania zawartości metali szkodliwych dla zdrowia (ołowiu, kadmu, cynku i miedzi) w środkach spożywczych wprowadzono metodę atomowej spektrofotometrii absorpcyjnej (ASA), która zastąpiła metodę kolorymetryczną. Badano i monitorowano pozostałości antybiotyków i leków weterynaryjnych (chloramfenikolu, oksytetracykliny, streptomycyny, sulfachinoksaliny, chloramfenikolu) w środkach spożywczych pochodzenia zwierzęcego. Obecność tych substancji w żywności była spowodowana nieprawidłowym nadzorem weterynaryjnym $\mathrm{w}$ hodowli zwierząt i nieprzestrzeganiem okresu karencji po lekach stosowanych u zwierząt.

Niezależnie od badań naukowych Zakład Badania Żywności i Przedmiotów Użytku PZH prowadził szeroką działalność usługową, ekspertyzową, opiniodawczą, konsultacyjną i szkoleniową.

W ramach działalności usługowej Zakład wydawał atesty jakości zdrowotnej na wyroby przeznaczone 
do kontaktu z żywnością, w tym wyroby gospodarstwa domowego i opakowania żywności, a także inne przedmioty użytku, takie jak kosmetyki, wyroby chemii gospodarczej, kredki, farbki i zabawki dla dzieci.

Działalność opiniodawcza dotyczyła substancji dodatkowych (m.in. barwników) dodawanych do żywności, zanieczyszczeń chemicznych i biologicznych stwierdzanych w żywności i preparatach dla niemowląt, a także środków kosmetycznych i środków do utrzymania czystości. Wydawano także opinie naukowe o nowych substancjach stosowanych w żywieniu zwierząt, które mogły znaleźć się w mięsie oraz o preparatach weterynaryjnych wykorzystywanych w leczeniu drobiu i zwierząt rzeźnych. Przeprowadzano także analizy odwoławcze w stosunku do żywności importowanej, np. na obecność aflatoksyn w orzechach arachidowych, ołowiu w sokach pomidorowych i rtęci w produktach dla dzieci.

Po przejściu profesora Nikonorowa w 1982 r na emeryturę kolejnymi kierownikami Zakładu Badania Żywności i Przedmiotów Użytku byli: prof. dr hab. Halina Mazur w latach 1981-1990 i doc. dr hab. Kazimierz Karłowski w latach 1990-2010. Od 2011 roku kierownikiem Zakładu jest dr Jacek Postupolski.

Pracownicy naukowi Zakładu Badania Żywności i Przedmiotów Użytku w sprawach jakości zdrowotnej żywności i przedmiotów użytku byli ekspertami dla Ministra Zdrowia, Ministra Rolnictwa, Ministra Handlu Zagranicznego i Centralnego Inspektoratu Standaryzacji, Polskiego Komitetu Normalizacji Miar i Jakości w sprawie wymagań zdrowotnych, metod analitycznych i pobierania próbek. Brali udział w posiedzeniach Komitetów Kodeksu Żywnościowego FAO/WHO oraz opiniowali dokumenty i normy międzynarodowe.

Obszar ekspertyzowy Zakładu obejmował zagadnienia leżące na pograniczu wielu dziedzin, dlatego w Zakładzie byli zatrudnieni biolodzy, mikrobiolodzy, farmaceuci, chemicy, żywieniowcy, technolodzy żywności i inżynierowie technologii rolno-spożywczej.

Systematycznie odbywały się też seminaria, na których pracownicy naukowi Zakładu omawiali wyniki własnych prac badawczych i prezentowali aktualną wiedzę na temat występowania aktualnych zagrożeń pochodzących z żywności. Organizowano także praktyczne szkolenia dla pracowników laboratoriów Wojewódzkich Stacji Sanitarno-Epidemiologicznych w celu wdrożenia nowych metod analitycznych przewidzianych do stosowania w rutynowej kontroli żywności $(2,21)$.

Okresem szczególnie wytężonej pracy dla Zakładu był okres przed wstąpieniem Polski do Unii Europejskiej w 2004 r. Wiązało się to z koniecznością przeglądu i dostosowania prawodawstwa krajowego do przepisów Unii Europejskiej z zakresu bezpieczeństwa żywności, materiałów i wyrobów do kontaktu z żywnością oraz kosmetyków, obszarów, za które Państwowy Zakład Higieny był odpowiedzialny merytorycznie i współpracował z Ministerstwem Zdrowia.

Należy podkreślić, że obecnie, gdy mija już 15 lat od wstąpienia Polski do UE, cele Zakładu pozostały niezmienione. Zmieniły się tylko metody badawcze i przybyły nowe wyzwania związane $\mathrm{z}$ rozwojem społecznym, postępem technicznym i pojawiającymi się nowymi zagrożeniami występującymi w żywności. Zmieniły się także kryteria oceny bezpieczeństwa. Nazwa Zakładu Badania Żywności i Przedmiotów Użytku w 2012 r. została zmieniona na Zakład Bezpieczeństwa Żywności. Zmianie uległy również nazwy Pracowni. Pracownicy naukowi Zakładu, od czasu wstąpienia Polski do Unii Europejskiej w 2004 r. stali się ekspertami Komisji Europejskiej uczestnicząc w tworzeniu nowych przepisów mających zapewnić bezpieczną żywność na wspólnym, unijnym rynku oraz ściśle współpracują z Europejskim Urzędem ds. Bezpieczeństwa Żywności (EFSA).

Zakład Bezpieczeństwa Żywności kontynuuje badania $\mathrm{w}$ zakresie chemicznego i mikrobiologicznego bezpieczeństwa żywności i wyrobów przeznaczonych do kontaktu z żywnością. Opracowuje, waliduje i wdraża nowe metody analityczne do rutynowej kontroli żywności. Pełni też funkcję Narodowego Laboratorium Referencyjnego (NRL) w zakresie chemicznych i biologicznych zanieczyszczeń żywności oraz materiałów do kontaktu z żywnością. Dokonuje oceny ryzyka dla zdrowia związanego z pobraniem szkodliwych zanieczyszczeń pochodzących z żywności i materiałów przeznaczonych do kontaktu z żywnością, w tym także dla potrzeb europejskiego Systemu Wczesnego Ostrzegania o Niebezpiecznej Żywności i Paszach (Rapid Alert System for Food and Feed - RASFF) (21) oraz ściśle współpracuje z Europejskim Urzędem ds. Bezpieczeństwa Żywności (EFSA). Kontynuowana jest również działalność opiniodawcza i usługowa, w tym także wydawanie, na zasadach dobrowolności, świadectw jakości zdrowotnej na materiały i wyroby do kontaktu z żywnością, preparaty dezynfekcyjne, wyroby chemii gospodarczej, kosmetyki i zabawki.

\section{PIŚMIENNICTWO}

1. Gromulska M. Filie Państwowego Zakładu Higieny. Przegl Epidemiol 2008;62:705-717.

2. Jeljaszewicz J. Państwowy Zakład Higieny a zdrowie publiczne. Roczniki Państwowego Zakładu Higieny 1998;59 (Supl.):113-122.

3. Krauze S. Materiały do Polskiego Kodeksu Żywnościowego, czyli ujednoliconych metod badania artykułów żywności i Przedmiotów Użytku. Farmaceutyczny Instytut Wydawniczy Naczelnej Izby Aptekarskiej im. Prof. Bronisława Koskowskiego, Warszawa, 1948 r. 
4. Krauze S. Osiągnięcia w dziedzinie badania i kontroli żywności oraz przedmiotów użytku w okresie 30-lecia Polskiej Rzeczypospolitej Ludowej. Roczniki Państwowego Zakładu Higieny 1975;26(3): 289-299.

5. Kołodziejska Z, Szczygieł A. Tablice witaminów (Z Oddziału Biochemii Państwowej Szkoły Higieny), Warszawa 1938 r.

6. Kałużewski S. Przyczynek do historii Państwowego Zakładu Higieny w latach 1945-1997. Roczniki Państwowego Zakładu Higieny 1998;49 (Supl.):101-111

7. Naruszewicz-Lesiuk D. Rola Państwowego Zakładu Higieny w perspektywie historycznej. [The role of the National Institute of Hygiene in historical perspective]. Roczniki Państwowego Zakładu Higieny 2008;59 (Supl.) 51-53.

8. Okna pamięci - sylwetki pracowników PZH. Roczniki Państwowego Zakładu Higieny 2008;59:69-89

9. Przesmycki F. Sprawozdanie z wykonania planu naukowej działalności na rok 1949 Państwowego Zakładu Higieny. Roczniki Państwowego Zakładu Higieny 1950;1(3-4):567-590

10. Rozporządzenie Ministra Zdrowia Publicznego w przedmiocie organizacji Państwowych Zakładów badania żywności i przedmiotów Użytku. Dz.U. z 1919 r., nr 71, poz. 420.

11. Rozporządzenie Ministra Zdrowia Publicznego w przedmiocie badania żywności i przedmiotów użytku publicznego. Dz.U. z 1919 r., nr 71, poz. 421.

12. Rozporządzenie Ministra Zdrowia Publicznego w przedmiocie taksy za badanie żywności i przedmiotów użytku publicznego w Państwowych Zakładach badania żywności i przedmiotów użytku. Dziennik Ustaw z 1919 r., nr 71, poz. 422.

13. Rozporządzenie Prezydenta Rzeczypospolitej z dnia 22 marca 1928 roku o dozorze nad artykułami żywności i przedmiotami użytku. Dziennik Ustaw z 1928 r, nr 36, poz. 343 , str. $755-761$.
14. Sprawozdania z działalności Państwowych Zakładów Badania Żywności i Przedmiotów Użytku w Warszawie, w Łodzi i w Krakowie za rok 1921 i 1922. Ministerstwo Zdrowia Publicznego, Warszawa 1923 r.

15. Sprawozdanie z działalności Państwowego Zakładu Higieny za rok 1924 i 1925. Warszawa 1926. Biblioteka PZH.

16. Sprawozdanie z działalności Państwowego Zakładu Higieny (1926-1927). Warszawa 1929. Biblioteka PZH.

17. Sprawozdanie z działalności Państwowego Zakładu Higieny za rok 1935. Warszawa 1936. Biblioteka PZH.

18. Sprawozdanie z działalności Państwowego Zakładu Higieny za rok 1936. Warszawa 1937. Biblioteka PZH

19. Sprawozdanie z działalności Państwowego Zakładu Higieny za rok 1937. Warszawa 1938. Biblioteka PZH

20. Sprawozdanie z działalności Państwowego Zakładu Higieny za rok 1938. Warszawa 1939. Biblioteka PZH

21. Sprawozdania $z$ działalności naukowej i usługowej PZH (1945-2018). Biblioteka PZH

22. Szkoła polskiej farmacji. Uczeni i ich dzieła. Prof. dr hab. Stanisław Krauze (1902-1977). Aptekarz Polski 2016 (http://www.aptekarzpolski.pl/2016/09/szkola-polskiej-farmacji-uczeni-i-ich-dziela-prof-dr-hab-stanislaw-krauze-1902-1977/)

23. Szczygieł A. Z historii nauki o żywieniu w Polsce 19261978. Warszawa, Biblioteka PZH.

Otrzymano: 23.11.2018 r.

Zaakceptowano do publikacji: 12.12.2018 r.

\section{Adres do korespondencji:}

Dr Kazimiera Ćwiek-Ludwicka

Narodowy Instytut Zdrowia Publicznego

- Państwowy Zakład Higieny

Ul. Chocimska 24

00-791 Warszawa

$\mathrm{Tel} /+48225421266$

e-mail: cwludwicka@pzh.gov.pl 